\title{
The Effectiveness Of K-W-L Technique To Increase Students' Reading Comprehension Achievement Through Reading Descriptive Text For Grade 8 of SMP Negeri 1 Cisarua
}

\author{
Nelson Balisar Panjaitan \& Radema Situmorang \\ sonnelunai@yahoo.co.id \\ School of Education, Universitas Advent Indonesia
}

\begin{abstract}
The purpose of this study is to find out whether there is a significant difference in reading comprehension achievement between those who are taught using the K-W-L (Know-Want to know-Learn) technique and those who are taught using the Conventional technique. In this study, the researcher used quantitative research. The participants of this study were students at SMP Negeri 1 Cisarua, Bandung. This study was conducted in ten meetings. This research was conducted in four steps: Pilot test, Pre-test, treatment (K-W-L technique) and post-test. After analyzing the data from the result of pre-test and post-test score it showed that there is significant difference in reading comprehension between those who are taught using K-W-L technique and those who are taught using conventional technique. Therefore, it can be concluded that the K-W-L technique as a teaching material has a positive impact in reading comprehension achievement.
\end{abstract}

Key Word: $K-W-L$ technique, Effectiveness, and Reading Comprehension.

\section{Introduction}

English is the most widely used language in international communication. Today, English is one of the languages of the people to communicate. It is supported by Nehemiah (2011) who said that acquiring English language as a communication tool in the era of globalization is required for those who participate in globalization in terms of business, culture, job, travel, technical knowledge, information, education and practice. For this reason, learning English is very important for us. If we can master the English language then it could become our devise to face the globalization era.

Because of the importance of the English language for all, schools have taught English lessons since elementary school. Not only for elementary schools, but today the English language is taught to children in playgroups. In other word, more importantly learning English is done through reading. Students often have problems when they read. The students do not understand what they read. According to Yeselson (2000) students have problems in reading comprehension, such as they cannot understand the text at all. They misread the text by totally changing its meaning, and they misread the text by taking words and phrase out of 
context. Katemba, C. \& Samuel (2017) stated that usually students face many problems in reading text. For example: difficult words, comprehension of sentences, how to read the word or sentence correctly, and etc. In reading class, most of the reading activities are focused on reading for comprehension. Further, Katemba, C. (2013) In Indonesian schools, however, the teaching of English consists mainly of learning correct grammatical structures or forms, increasing vocabularies, working on exercises on the sentence level, and asking students to repeat over and over similar structures.

In addition, students also often experience boredom when they read. They even feel depressed when they do not understand what they read from the reading text. Sasson (2007) said that students can become easily frustrated when they do not understand what they are reading and as a result, they lose their motivation. In other word, as a teacher we must be creative to devise reading materials to teach the students the different techniques to help students understand reading. Base on the problems above, the researcher is interested in researching about teaching reading by using K-W-L technique. K-W-L (Know-Want to knowLearn) technique is a chart which consists of three columns: know, want to know and learned. The first column is "Know". In this column, the students write down about what they have known about the topic that will be discussed by the writer in the text. The second column is "Want to know". In this column the student is concerned with what they want to know more about the topic. In the last column "Learned" which is part of the K-W-L technique, the students need to provide answers based on the questions in column "What to Know" after reading the text. Sasson (2008) said that K-W-L technique can help the teachers to make students more interested in learning to read, because the students will think about what they want to know and what they have learned. Besides that, K-W-L technique will help students become better readers. According to Carr and Ogle (1987) reading by using $\mathrm{K}-\mathrm{W}-\mathrm{L}$ chart means that this chart in reading the text will help to activate their prior knowledge to be an active reader and critical reader.

Philip (2010) also said that K-W-L technique is more appropriate for students with high interest while Direct Instructional Method is more appropriate for low interest students. His research can be concluded that there is interaction effect between the two variables, teaching method and interest. In this case, K-WL technique would be more appropriate to be used for students to improve their knowledge in reading comprehension.

From the statement of the K-W-L technique, the researcher would try to do some research by using $\mathrm{K}-\mathrm{W}-\mathrm{L}$ technique in teaching reading comprehension for Junior high school.

Related to the study entitle "The Effectiveness of K-W-L Technique to Increase Students Reading Comprehension Achievement Through Reading Descriptive Text for Grade 8 Class of SMP Negeri 1 Cisarua", this study attempts to answer the following question:

Is there any significant difference in reading comprehension between those who are taught using $K-W$-L technique and those who are taught using conventional technique? 
Many kinds of the techniques that can be used to teach reading comprehension.

However, in this study the researcher focused on the technique for teaching reading comprehension by using of K-W-L technique. The researcher chose two classes of grade 8 Junior high school year 2013/2014 in SMP Negeri 1 Cisarua Bandung as the population.

The aim of this study is to find out whether the K-W-L technique can increase students' reading comprehension.

This study makes use of the following hypothesis:

Ho $=$ There is no significant difference in reading comprehension between those who are taught using K-W-L technique and those who are taught using conventional technique.

$\mathrm{Ha}=$ There is a significant difference in reading comprehension between those who are taught using K-W-L technique and those who are taught using conventional technique.

This study is expected to be a reference and one of the alternatives in teaching reading descriptive text for English teachers. The findings of this study will be beneficial to students, educators, course developers, and researchers in many aspects.

Students, The result of this study will help students to be more interested in reading after using the $\mathrm{K}-\mathrm{W}-\mathrm{L}$ technique.

Educators, The educators can help students to improve the reading ability through $\mathrm{K}-\mathrm{W}$-L technique that works well for students in elementary levels.

Course Developers, This study can help curriculum developers to use K-W-L technique, as one of the method in teaching English.

Researchers. This study is also expected to contribute to the other researcher.

\section{Research Methodology}

In this study the researcher used quantitative method with experimental design. This experimental design compares the students reading comprehension achievement between the experimental group and the control group. According to Russeffendi (2010) the design of the researcher is as follow.

Table 1 Research design

\begin{tabular}{|l|l|l|l|}
\hline GROUP & PRE-TEST & TREATMENT & POST-TEST \\
\hline Experimental & $\mathrm{X}_{1}$ & $\mathrm{~T}$ & $\mathrm{X}_{2}$ \\
\hline Control & $\mathrm{X}_{1}$ & $\mathrm{O}$ & $\mathrm{X}_{2}$ \\
\hline
\end{tabular}

The explanation:

$\mathrm{X}_{1}=$ Score of students in pre-test.

$\mathrm{T}=$ Treatment application the sing K-W-L technique

$\mathrm{X}_{2}=$ Score of students in post-test.

$\mathrm{O}=$ Control group without treatment. 
The table shows that this study involved two groups, an experimental group and a control group. The experimental group received a K-W-L treatment, while the control group received non $\mathrm{K}-\mathrm{W}$-L treatment.

Fraenkel \& Wallen (2006) stated that there are two types of variables in this research. They are independent variable and dependent variable. In this research, the independent variable of the study is K-W-L technique and dependent variable is students' reading comprehension achievement.

The population of this study was grade 8 students in SMP Negeri 1 Cisarua, Bandung year 2013/2014. The researcher chose two classes randomly grade $8 \mathrm{C}$ and grade $8 \mathrm{~A}$ class. In grade $8 \mathrm{C}$ class there were 38 students as an experimental group and grade $8 \mathrm{~A}$ class there were 36 students as a control group. The total number of students there were 74 students.

The instruments used were the pre-test and post-test taken from the National Government test for Junior High School. The grade $8 \mathrm{C}$ class as an experimental group was taught by using $\mathrm{K}-\mathrm{W}-\mathrm{L}$ technique. The grade $8 \mathrm{~A}$ class as the control group was taught using the conventional technique.

The researcher focused on descriptive text as the K-W-L technique to teach reading. Descriptive text is a text that describes a particular person or thing. In other words that descriptive text is easier for the student to understand. (Sudarwati and Grace 2007).

Pilot test was conducted on January 28, 2014 to grade 9A in SMP negeri 1 Cisarua, Bandung. Pilot test was conducted to select appropriate questions from the instrument. The test consisted of 55 multiple choice questions with four options A, B, C and D. The questions was analyzed to check their, validity, difficulty level, discrimination index reliability and practically to ensure that they can be used for pre-test and post-test. To analyze the data of pilot test the researcher used Anates statistic.

The pre-test was administered on January 31, 2014. There were thirty one questions for the pre-test as multiple choices questions. Both of experimental and control group did the same test. Grade 8A were 34 students and grade $8 \mathrm{C}$ were 38 students. The test was adapted from the National Government test for Junior High School. The time frame to do the pre-test was only 90 minutes.

Respondents were divided into two groups; experimental and control group students of the grade $8 \mathrm{C}$ and the grade $8 \mathrm{~A}$. The treatment started on February 3, 2014 up to February 28, 2014. The researcher taught twice a week, each class meeting were $2 \times 45$ minutes. The total hours for doing this study were 32 hours.

The implementation of K-W-L technique to teach reading comprehension is following the Teaching Model of Ogle (1986).

The researcher asked students to take out a sheet of notebook paper and made three columns. They wrote a "K" over the left column, "W" over the center column and "L" over the right column. 


\begin{tabular}{|l|l|l|}
\hline Column 1 & Column 2 & Column 3 \\
\hline $\begin{array}{l}\text { What we Know } \\
\text { (K) }\end{array}$ & $\begin{array}{l}\text { What we Want to know } \\
\text { (W) }\end{array}$ & $\begin{array}{l}\text { What we Learned } \\
\text { (L) }\end{array}$ \\
\hline & & \\
\hline
\end{tabular}

The researcher explained to students that $\mathrm{K}$ stands for what the students already knows about the topic they are studying. Tell the students what the topic is about, and ask them to share facts they already know.

The researcher explained that the $\mathrm{W}$ stands for what the students want to learn about the topic. The researcher will write all the questions the students ask on the board and tell them to write the same on their papers under the $\mathrm{W}$.

The researcher instructed the students to read the text. This may be done orally as a class or silently and individually. Tell the class to mark items in their $\mathrm{K}$ lists as true or false based on what they learn in the text. Also tell them to put stars next to questions in the $\mathrm{W}$ list if the text answers those questions.

Discussed what they discovered as a class after they have read from the text and made notes on their first two columns. Tell the students that $\mathrm{L}$ stands for what they have learned. Give them time to write down new things they have learned that did not appear in the $\mathrm{K}$ or $\mathrm{W}$ columns.

At the end of the session the researcher gave work sheet 2 as a home work. The post-test was administered in the last meeting on March 3, 2014. Both of experimental and control group did the same test. The purpose of this test was to find out if there was any significant difference after the treatment of K-W-L technique. There were thirty one questions for the post-test as multiple choices questions. The test was adapted from the National Government test for Junior High School. The time frame to do the post-test was only 90 minutes.

This chapter presents the result of data analysis and findings based on normality, homogeneity and t-test to see if there is any significance difference in reading comprehension between those who are taught using K-W-L technique and those who are taught using conventional technique.

\section{Data Analysis And Findings}

In gathering data, the researcher used the following procedures: Conducting the pre-test. The researcher gave a multiple choice questions test which consisted of 31 questions and was administered to 68 students. Applying the treatment. The researcher used K-W-L technique to teach reading for 10 meetings in grade $8 \mathrm{C}$ students.

Conducting post-test.

After the treatment, the researcher conducted a post-test and used the same procedures as the pre-test procedures. The post-test was administered to 68 
students and each group has 34 students. The post-test used to check the two groups' scores to investigate significant difference between two methods.

Scoring. The score was given based on the participants' correct answer, and the perfect score was 100 .

Interpreting the score. To interpret the result of this study, the researcher used t-test to find the significance difference between pre-test and post-test.

This table shows the descriptive statistic for the pre-test, post-test and normalized gain.

Table 2. Normalized Gain

\begin{tabular}{|l|l|l|l|l|}
\hline \multirow{2}{*}{ Class With } & \multicolumn{2}{|l|}{ K-W-L Techniques } & \multicolumn{2}{l|}{ Conventional Method } \\
\cline { 2 - 5 } & Mean & St. deviation & Mean & St. deviation \\
\hline Pre-test & 49.73 & 7.85 & 51.67 & 13.79 \\
\hline Post-test & 69.41 & 8.70 & 62.26 & 15.19 \\
\hline Gain & 0.39 & 0.15 & 0.21 & 0.21 \\
\hline
\end{tabular}

Here are some examples of the students' normalized gain calculations:

Normalized gain for Agung (student no 1 appendix A page 44)

$$
\begin{aligned}
<g> & =\frac{67-41}{100-41} \\
& =0.44
\end{aligned}
$$

Normalized gain for Agus Kresna Reformansyah

$$
\begin{aligned}
<g> & =\frac{58-41}{100-41} \\
& =0.28
\end{aligned}
$$

Here are some examples of the students' normalized gain calculations:

Normalized gain for Ahmad Fauzy Darussalam (student no 1 appendix B page 46 )

$$
\begin{aligned}
<g> & =\frac{83-54}{100-54} \\
& =0.63
\end{aligned}
$$

Normalized gain for Citra Mega Mayasari (student no 2 appendix B page 46)

$$
\begin{aligned}
<g> & =\frac{64-48}{100-48} \\
& =0.30
\end{aligned}
$$

It can be seen from the table 4.1 above that the average normalized gain of the students who are taught using the K-W-L technique is higher than the students who are taught using the conventional method.

Conclusion 
From the calculation of the data, the researcher can draw the following conclusion. K-W-L technique is more effective in teaching reading comprehension achievement than conventional technique. This could be seen on the gain based on mean of the experimental and control group. The gain of the experimental group was .3932 and the mean value of post-test was 69.41 while the gain of the control group was .2179 and the mean value of post-test was 62.26. From the explanation above, that K-W-L technique could increase students' reading comprehension achievement through reading descriptive text.

It is supported by Sasson (2008) who said that K-W-L technique can help the teachers to make students more interested in learning to read, because the students will think about what they want to know and what they have learned. Ogle (1986) explained that $\mathrm{K}-\mathrm{W}-\mathrm{L}$ is an instructional reading technique used to guide students through a text which is begun by brainstorming everything they know about the topic.

Backman (2006) indicated that K-W-L technique is a good strategy because it enabled the teachers to assess students' background knowledge and interests before the lecture. Afterward, it helps instructors to evaluate the content material that were learned. K-W-L technique represented as a class activity or an individual basis. 


\section{References}

Ahmad, I. S. \& Asraf, R. M (2004). Making sense of text: Strategies used by good and average readers. Reading Matrix, 26-37.

Akyol, H. (2006). Türkçe öğretim yöntemleri.[Turkish teaching methods]. Ankara: KökPublication.

From:http://www.readingmatrix.com/articles/asraf ahmad/article.pdf

Arikunto, S (2009). Dasar- Dasar Evaluasi Pendidikan. Jakarta: Bumi,Aksara.

Arikunto S.(2013) Dasar-dasar Evaluasi Pendidikan. Bumi Aksara. Jakarta.

Bader, C. (2007). KWL plus reading strategy. Retrieved on November 16, 2013 from http://hercules.gcsu. edu/ cbader/5210SPED/kwl.htm.

Bailey, D. W. (2002). KWL-plus. Unpublished manuscript, Johns Hopkins University, School of Professional Studies in Business and Education, Baltimore.

Backman,Leslie Opp \&Klinglammer, Sarah (2006) Shaping The Way We Teach. The office of English Language Programs: United States Department of state, Washington, Dc20547, 2006. E-_mailiaei@uoregon.edu.

Bos, C. S. \& Vaughn, S. (2002). Strategies for Teaching Students with Learning and Behavior Problems. Boston: Allyn and Bacon.

Brantmeier, C. (2002). Second language reading strategies research at the secondary and university levels: Variations, disparities and generalizability. Reading Matrix, 1-14. Retrieved on November 14, 2013, from:http://www.readingmatrix.com/articles/brantmeier/article.pdf

Brown, H.D. (2001). Teaching by Principles: an Interactive Approach to Language Pedagogy $\left(2^{\text {th }}\right.$ ed). England: Longman.

Carr, E. \& Ogle, D. (1987). KWL Plus: A strategy for comprehension and summarization. Journal Reading, 30(7), 626-631.

Conner, Jennifer (2006) Advanced study of the Teaching of Secondary school Reading. Instructional reading strateg . http : \ www . Indiana . edu \ - $1517 \backslash$ KWL. Htm.

Djuharie, O.S. (2010). Bahasa Inggris untuk SMA/MA. Bandung:CV. YRAMA WIDYA. 
Fraenkel, J.R. \& Wallen, N.E. (2006).How to Design and Evaluate Research in Education $6^{\text {th }}$ ed. McGraw-Hill: New York: NY.

Gerot, Linda and Peter Wignell (1995). Making Sense of Functional Grammar Sydney: Antipodean educational Enterprise.

Grabe, William and Stoller (2002) Fredericka L. Teaching and Researching Reading. $\quad$ London: Pearson Education Longman.

Jones, Raymondc . (2007) strategies for Reading Comprehension. htti $\backslash \backslash$ www . reading quest . org $\backslash$ strxat $\backslash \mathrm{kwl}$.html.

Katemba, C. (2013). Anxiety Level of Indonesian Students and Its Relationship To Academic Achievement In English. Journal of Education and Practice Vol.4 No.27, 2013 http://www.iiste.org/Journals/index.php/JEP/article/view/9873/10097

Katemba, C. \& Samuel (2017). Improving Student's Reading Comprehension Ability Using Jigsaw 1 Technique. Acuity: Journal of English Language Pedagogy, Literature and Culture. Vol. 2, No. 2 Universitas Advent Indonesia. http://jurnal.unai.edu/index.php/acuity/article/view/613/468

Nehemiah, (2011). Role of English as a Tool for Communication in Tamil Society. Retrieved on October 11, 2013 from http://www.languageinindia.com/aug2009/santhienglish.html

Ogle, D. (1986). KWL: A teaching model that develops active reading in expository text. The Reading Instructor, 39(6), 564-570.

Oxford, R.\& Crookall, D.(1989). Research on language learning strategies: Methods, findings, and instructional issues. Modern Language Journal, 73, 404-419.

Pardo, L. S. (2004). What every teacher needs to know about comprehension. The Reading Teacher, 58(3) 272-281.

Philip, A. (2010). The effectiveness of kwl (know, want to learn, learned) in teaching of reading viewed from students' English learning interest (an experimental research in the ninth grade students of SMP negeri 8 Probolinggo academic year 2009-2010) (Unpublished thesis). English Education Department Sebelas Maret University of Surakarta, Surakarta.

Russeffendi ET., (1998) Statistika Dasar untuk PENELITIAN Pendidikan, Bandung, IKIP 19539-9. Sa 
Russeffendi ET., (2010). Dasar-dasar Penelitian Pendidikan \& Bidang NonEksakta Lainnya. Tarsito: Bandung.

Sasson, D. (2008). Use K-W-L Technique in Reading Lessons. Retrieved on November 8, 2013 from: http://suite101.com/a/strategic-lesson-planningfor- teaching-reading-a60272.

Sasson, D. (2007). How to teach Reading Strategies. Retrieved on October 8, 2013, from http://www.suite 101.com/content/how-to-tech-reading strategiesa17034.

Sinurat, V. M. (2011). Pengaruh pembelajaran kooperatif tipe STAD (Student Teams Achievement Division) terhadap peningkatan kemampuan bahasa garis singgung lingkaran. Skripsi Bandung: UNAI

Steven (2009), teaching reading comprehension. Retrieved on November 20, 2013

from:http://www.readingresource.net/teachingreadingcomprehension.html

Sudarwati, T.M \& Grace, E. (2007). Look Ahead: An English Course for Senior High School Students Year XI. Jakarta: Erlangga.

Sudarwati and Eudia Grace. Look Ahead 2. 2005. Penerbit Erlangga. Jakarta.

Sugiono, Dr (2010). Metode penelitian Kuantitatif Kualitatif dan R\&D, penerbit Alfabeta.

Sopiyudin, D. (2009). Statistik Untuk Kedokteran Dan Kesehatan. Jakarta : Salemba Medika.

Surapranata, Sumarna. 2009. Analisis, Validitas, Reliabilitas, Dan Interpretasi Hasil Tes. Cetakan keempat. Bandung: PT. Remaja Rosdakarya Offset.

Uyanto, S. S. (2009). Pedoman Analysis Data dengan SPSS. Yogyakarta: Graha Ilmu.

Vacca, R.T \& Vacca, J.A.L. (2008). Content Area Reading (Ninth Edition): Literacy and Learning across the Curriculum. New York: Pearson Education, Inc.

Yeselson, (2000). Common Reading Comprehension Problems and Basic Exercise. Retrieved on October 8, 2013. from:http://docs.goole.com/viewer? $\mathrm{a}=\mathrm{v} \& \mathrm{q}=$ cache:obIYQpAt1hoJ:planger

e .rutgers.edu/documents/tutors/commonreadingcomprehentionproblems.pdf 